\title{
Pengaruh Komposisi Lelehan dan Waktu Celup terhadap Struktur Mikro lapisan Hot Dip Aluminizing pada Baja Tahan Karat MartensitiK
}

\section{EFFECT OF COMPOSITION AND TIME OF Dip ON THE MiCROSTRUCtURE OF Hot Dip ALUMinizing of MARTENSITIC StaINLESS STEEL}

\author{
Kevin ${ }^{1}$, Moch. Syaiful Anwar ${ }^{2 *}$, Saefudin ${ }^{2}$, Alfirano ${ }^{1}$ and Efendi Mabruri ${ }^{2 *}$ \\ ${ }^{1}$ Jurusan Teknik Metalurgi, Fakultas Teknik, Universitas Sultan Ageng Tirtayasa, Cilegon, 42435, Indonesia \\ ${ }^{2}$ Pusat Penelitian Metalurgi dan Material, LIPI, Kawasan PUSPIPTEK Gedung 470, Tangerang Selatan, \\ 15314, Indonesia \\ E-mail:moch026@lipi.go.id,msyifulan04@gmail.com,efendi_lipi@yahoo.com
}

\begin{tabular}{|c|c|}
\hline ARTICLE INFO & Abstract \\
\hline $\begin{array}{l}\text { Article history } \\
\text { Received date } \\
2018-04-13 \\
\text { Received in revised form date } \\
\text { 2018-09-07 } \\
\text { Accepted date } \\
\text { 2018-09-21 } \\
\text { Available online date } \\
\text { Mei } 2019\end{array}$ & $\begin{array}{l}\text { In high temperature application materials, surface coating is important in } \\
\text { providing high temperature oxidation and corrosion resistance, erosion, } \\
\text { and abrasion resistance. Aluminum coating on AISI } 410 \text { martensitic stain- } \\
\text { less steel by hot dipping method is effective enough to provide substrate } \\
\text { protection through intermetallic compounds that are formed. Al-Si melt } \\
\text { composition, dipping time, and diffusion time influence the intermetallic } \\
\text { layers formed along with their mechanical properties. The morphological } \\
\text { characterization of hot dip aluminizing coating on martensitic stainless } \\
\text { steel specimens coated by Al Pure, } 5 \% \mathrm{wt} S \mathrm{Si}, 10 \mathrm{wt} \text {. Si, and } 15 \mathrm{wt} \text {. Si with } \\
\text { variation of dyeing time of } 1 \text { min, } 3 \mathrm{~min} \text { and } 5 \mathrm{~min} \text {. In melt composition with } \\
\text { a } 5 \% \text { wt } \mathrm{Si} \text { composition with the same surface treatment by } \mathrm{H}_{2} \mathrm{SO} \mathrm{O}_{4} \text { solution } \\
\text { gives better intermetallic coating results. It can be seen from the fineness } \\
\text { of the microstructure and layer thickness produced based on the variation } \\
\text { of the immersion time. The Si element gives an influence in changing the } \\
\text { morphology of the interface structure between intermetallic and substrate. }\end{array}$ \\
\hline
\end{tabular}

Keywords: Aluminizing, Intermetallic, Effect of dipp time, Martensitic stainless steels.

Kata kunci:

Aluminizing

Intermetalik

Efek waktu pencelupan

Baja tahan karat martensitik

\begin{abstract}
Abstrak
Pada material aplikasi suhu tinggi, pelapisan permukaan merupakan hal penting dalam memberikan ketahanan oksidasi dan korosi suhu tinggi, ketahanan erosi dan abrasi. Pelapisan alumunium pada baja tahan karat, martensitik AISI 410 melalui metode celup panas (hot dip) cukup efektif untuk memberikan perlindungan pada substrate melalui senyawa-senyawa intermetalik yang terbentuk. Proses hot dip aluminizing dilakukan dengan preparasi penghalusan permukaan sampel menggunakan amplas grit 100, 400, 800, dan 1200. Kemudian sampel dibersihkan menggunakan larutan $15 \% \mathrm{H}_{2} \mathrm{SO}_{4}$ sebelum dilakukan proses celup panas. Spesimen tersebut dikaitkan menggunakan kawat nikel untuk memudahkan proses pencelupan. Komposisi lelehan Al-Si, waktu pencelupan dan waktu difusi memberikan pengaruh terhadap lapisan intermetalik yang terbentuk beserta sifat mekanisnya. Telah dilakukan karakterisasi morfologi lapisan hot dip aluminizing pada spesimen baja tahan karat martensitik yang dilapisi oleh Al Murni, $5 \%$ wt Si, $10 \%$ wt Si, dan $15 \%$ wt Si dengan variasi waktu pencelupan 1 menit, 3 menit, dan 5 menit dengan menggunakan SEM-EDS. Pada komposisi lelehan dengan komposisi 5\%wt Si dengan perlakuan permukaan yang sama oleh larutan $\mathrm{H}_{2} \mathrm{SO}_{4}$ memberikan hasil lapisan intermetalik yang lebih baik. Dapat dilihat dari kehalusan struktur mikro dan ketebalan lapisan yang dihasilkan berdasarkan variasi waktu pencelupan. Unsur Si memberikan pengaruh dalam mengubah morfologi struktur antarmuka antara intermetalik dengan substrate.
\end{abstract}




\section{PENDAHULUAN}

Baja tahan karat martensitik merupakan material yang diaplikasikan sebagai sudu turbin uap. Seiring dengan lama penggunaannya, baja tahan karat martensitik sering mengalami kerusakan (Saidi et al. 2014). Melihat kerugian yang mungkin terjadi, maka perlu dilakukan metode pelapisan (coating) untuk melindungi baja dari kerusakan.

Metode pelapisan menggunakan paduan Co pada permukaan baja tahan karat martensitik untuk aplikasi sudu turbin uap hingga saat ini masih merupakan proses yang membutuhkan biaya yang relatif tinggi, baik dari segi bahan pelapis maupun dari segi metode pelapisan yang digunakan, yaitu dengan metode pack cementation (Ebrahimifar et al. 2013). Sifat mekanis pada sudu turbin uap diperlukan sifat yang kuat, tahan abrasi, dan korosi.

Proses celup panas aluminium (hot dip aluminizing) merupakan salah satu alternatif metode pelapisan yang dapat digunakan. Selain lebih murah jika dibandingkan pack cementation, metode ini mudah dalam pengaplikasiannya, tahan terhadap panas dan oksidasi pada baja karbon.

Hot dip aluminizing coating merupakan proses pelapisan logam dengan aluminium pada baja sebagai subtrat, yaitu dengan mencelupkan baja ke dalam bak yang berisikan aluminium cair. Aluminium coating pada subtrat baja dapat membentuk lapisan $\mathrm{Al}_{2} \mathrm{O}_{3}$ padapermukaan baja sehingga baja dapat dilindungi (Liu et al. 2005). Selain itu, lapisan aluminium kemungkinan akan membentuk paduan intermetalik Fe-Al pada interface lapisan aluminium dan substrat baja. Pada penelitian sebelumnya telah dilakukan proses cladding melalui proses rolling panas untuk menghasilkan paduan intermetalik Fe-Al (WANG et al. 2014).
Penelitian ini bertujuan untuk optimalisasi komposisi lelehan aluminium terhadap terbentuknya paduan intermetalik Fe-Al dalam lapisan hot dip aluminizing pada baja tahan karat martensitik serta mengobservasi hasil paduan intermetalik Fe-Al pada interface lapisan aluminium dan substrat baja.

\section{METODE}

Sampel penelitian merupakan baja tahan karat (stainless steel) martensitik dengan komposisi $13 \% \quad \mathrm{Cr}$ yang berukuran $2 \times 1,5 \times 0,5 \mathrm{~cm}$. Proses hot dip aluminizing meliputi persiapan permukaan sampel, pembersihan permukaan sampel secara kimiawi, dan pelapisan hot dip aluminizing. Persiapan permukaan sampel dengan cara mengamplas sampel menggunakan amplas grit 100, 400, 800, dan 1200 untuk menghilangkan kotoran, minyak, debu, dll. Kemudian, sampel dicelupkan ke dalam larutan $15 \% \mathrm{H}_{2} \mathrm{SO}_{4}$ untuk menghilangkan lapisan oksida yang ada di atas permukaan sampel, lalu dikeringkan. Untuk memudahkan proses hot dip aluminizing, sebelumnya sampel baja tersebut dikaitkan menggunakan kawat. Variasi komposisi lelehan aluminizing adalah $\mathrm{Al}$ murni, 95\% $\mathrm{Al}+$ $5 \% \mathrm{Si}, 90 \% \mathrm{Al}+10 \% \mathrm{Si}$, dan $85 \% \mathrm{Al}+$ $15 \% \mathrm{Si}$, sedangkan variasi waktu proses hot dip aluminizing yaitu 1, 3, dan 5 menit. Proses perlakuan panas (heat treatment) hanya dilakukan pada sampel dengan waktu pencelupan 3 menit pada tiap komposisi lelehan setelah proses hot dip aluminizing. Proses perlakuan panas dilakukan dalam tungku muffle (muffle furnace) carbolite pada suhu $700^{\circ} \mathrm{C}$ selama 3 jam, kemudian didinginkan di udara. Setelah itu, dilakukan pengamatan ketebalan dan komposisi kimia lapisan aluminizing pada baja tahan karat martensitik dengan menggunakan Scanning Electro Microscopy-Energy 
Dispersive X-Ray Spectroscopy (SEMEDS JEOL 6390LA).

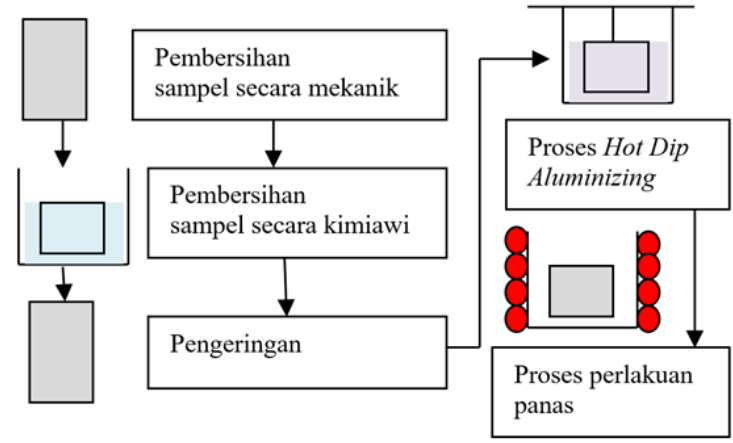

Gambar 1. Ilustrasi proses hot dip aluminizing

\section{HASIL DAN PEMBAHASAN}

Pengaruh Komposisi dan Waktu Pencelupan terhadap Ketebalan Lapisan Hot Dip Aluminizing

Gambar 2 menunjukkan hasil ketebalan lapisan hot dip aluminizing dengan variasi komposisi. Sampel dengan komposisi Al murni mengalami peningkatan ketebalan pada tiap penambahan waktu pencelupan yang digunakan. Hal ini dapat disimpulkan bahwa penambahan waktu pencelupan pada komposisi Al murni akan meningkatkan ketebalan lapisan (Citrawati and Mabruri 2009). Sampel penelitian dengan penambahan $5 \%$ dan $15 \%$ Si mengalami penurunan nilai ketebalan dari 1 menit pencelupan hingga 3 menit waktu pencelupan, setelah itu mengalami peningkatan ketebalan pada waktu pencelupan 5 menit. Penurunan ketebalan tersebut dapat diasumsikan sebagai pengaruh atom silikon yang menempati vakansi-vakansi pada morfologi $\left(\mathrm{Fe}_{\mathrm{x}} \mathrm{Al}_{\mathrm{y}}\right)$, sehingga fasa yang terbentuk menjadi ( $\mathrm{Fe}_{\mathrm{x}}$ $\mathrm{Al}_{\mathrm{y}} \mathrm{Si}_{\mathrm{z}}$ ) yang tumbuh secara lambat pada fasa $\left(\mathrm{Fe}_{\mathrm{x}} \mathrm{Al}_{\mathrm{y}}\right.$ ) (Awan and ul Hasan 2008). Sementara itu, pada waktu pencelupan 5 menit terjadi peningkatan ketebalan kecuali pada komposisi 10\% $\mathrm{Si}$ yang mengalami penurunan ketebalan. Peningkatan ketebalan tersebut dipengaruhi oleh laju difusi unsur Fe berdasarkan hukum Fick:

$\mathrm{d} c / \mathrm{d} t=\left[\left(\mathrm{k}_{1} \mathrm{~S}\right) / V\right]\left(\mathrm{c}_{\mathrm{s}}-\mathrm{c}\right)$

yakni $\mathrm{d} c / \mathrm{d} t$ adalah laju pertumbuhan $\mathrm{Fe}, \mathrm{S}$ adalah luas permukaan lapisan, $\mathrm{V}$ adalah volume lelehan, dan c adalah kelarutan Fe pada lelehan. Persamaan tersebut dapat diturunkan menjadi persamaan konstanta laju difusi menjadi;

$\mathrm{k}_{1}=\mathrm{D} / \delta$

yakni, $\mathrm{k}_{1}$ adalah konstanta laju $\mathrm{Fe}$, $\mathrm{D}$ adalah koefisien difusi atom $\mathrm{Fe}$, dan $\delta$ adalah ketebalan lapisan coating. Dengan demikian, dapat disimpulkan penambahan $\mathrm{Si}$ meningkatkan laju pertumbuhan $\mathrm{Fe}$ karena penambahan Si meningkatkan kelarutan $\mathrm{Fe}\left(\mathrm{c}_{\mathrm{s}}\right)$ pada persamaan (1).

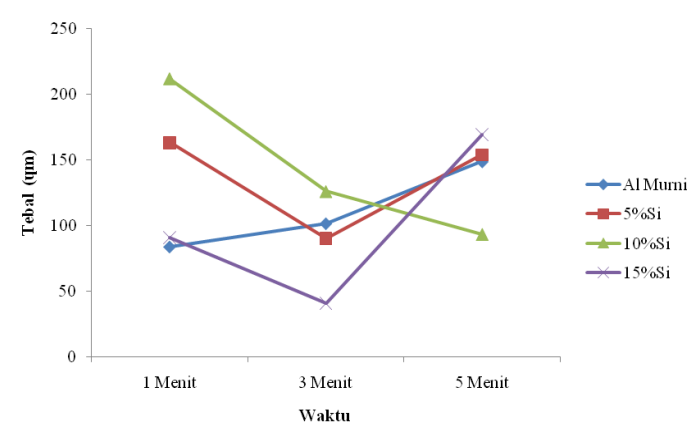

Gambar 2. Ketebalan lapisan hot dip aluminizing dengan komposisi Al Murni, $95 \% \mathrm{Al}+5 \% \mathrm{Si}$, $90 \% \mathrm{Al}+10 \% \mathrm{Si}$, dan $85 \% \mathrm{Al}+15 \% \mathrm{Si}$.

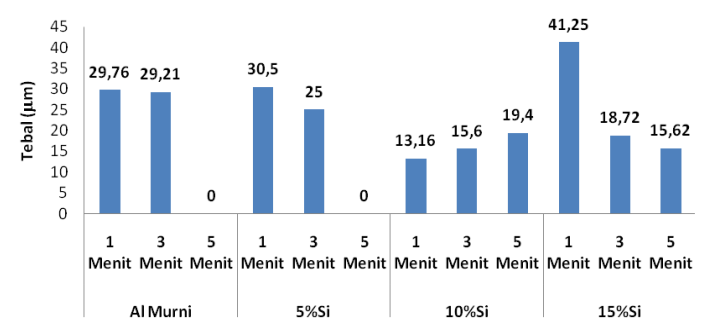

Gambar 3. Ketebalan lapisan intermetalik komposisi $\mathrm{Al}$ Murni, 95\% $\mathrm{Al}+5 \% \mathrm{Si}$, 90\%Al+ $10 \% \mathrm{Si}$, dan $85 \% \mathrm{Al}+15 \% \mathrm{Si}$. 
Gambar 3 menunjukkan ketebalan lapisan intermetalik hasil dari hot dip aluminizing dengan nilai yang bervariasi. Ketebalan lapisan intermetalik terbesar dimiliki sampel pada penambahan 15\% Si dengan waktu pencelupan 1 menit. Sementara, lapisan intermetalik paling tipis dimiliki oleh sampel pada penambahan $10 \% \mathrm{Si}$ dengan waktu pencelupan 1 menit.

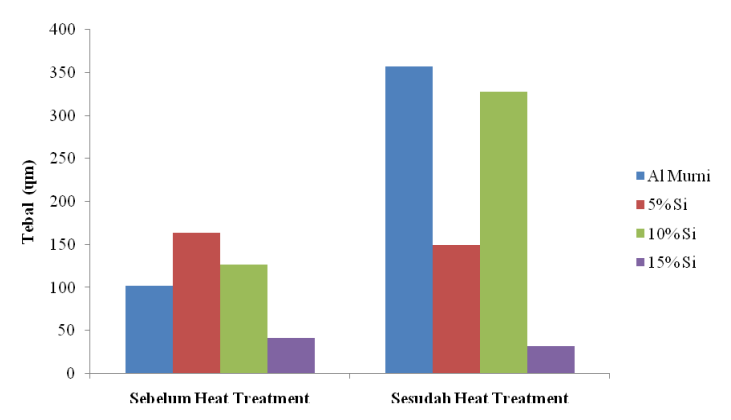

Gambar 4. Ketebalan total lapisan hot dip aluminizing pada waktu pencelupan 3 menit sebelum dan setelah heat treatment pada suhu $700^{\circ} \mathrm{C}$ selama 3 jam.

Gambar 4 menunjukkan ketebalan lapisan sebelum dan setelah dilakukan proses laku panas (heat treatment) pada temperatur $700^{\circ} \mathrm{C}$ selama 3 jam. Peningkatan ketebalan terjadi karena adanya difusi atom-atom dari substrat ke arah lapisan atau sebaliknya, sehingga terbentuknya lapisan difusi, lapisan yang awalnya telah terbentuk setelah proses pencelupan dilakukan menjadi semakin tebal (Citrawati and Mabruri 2009) yang dapat dilihat pada komposisi Al murni dan 10\% Si. Sementara, pada komposisi 5\% Si dan 10\% Si terjadi penurunan ketebalan total dan lapisan intermetalik. Dari uraian tersebut dapat disimpulkan bahwa akibat dari difusi antara Al dan Fe dengan senyawa Al-rich dan Si-rich berdifusi dengan $\alpha-(\mathrm{Fe})$, sehingga ketebalan lapisan berkurang.

\section{Pengaruh Komposisi dan Waktu Pencelupan terhadap Struktur Mikro Lapisan Hot Dip Aluminizing}

Hasil pengamatan lapisan intermetalik dari masing-masing sampel menunjukkan adanya morfologi finger-like seperti yang ditunjukkan pada Gambar 5. Permukaan intermetalik yang mengarah ke lapisan pada Al murni yang semakin halus ketika penambahan Si dilakukan (Awan and ul Hasan 2008; Citrawati and Mabruri 2009; Kobayashi and Yakou 2002; Wang and Shi 2004). Morfologi ini terbentuk akibat dari pertumbuhan senyawa $\mathrm{Fe}_{\mathrm{x}} \mathrm{Al}_{\mathrm{y}}$ yang arah pertumbuhannya lebih menyukai ke arah terjadinya difusi. Pertumbuhan $\mathrm{Fe}_{\mathrm{x}} \mathrm{Al}_{\mathrm{y}}$ yang anisotropik inilah yang menyebabkan terbentuknya morfologi menyerupai jari atau lidah (Citrawati and Mabruri 2009). Efek dari waktu pencelupan tidak menunjukkan perubahan yang signifikan pada morfologi tersebut. Dari pengamatan variasi komposisi, semakin besar penambahan $\mathrm{Si}$, maka semakin halus morfologi finger-like tersebut dan juga mengurangi ketebalan lapisan intermetalik karena adanya difusi atom-atom Si ke arah lapisan Al.
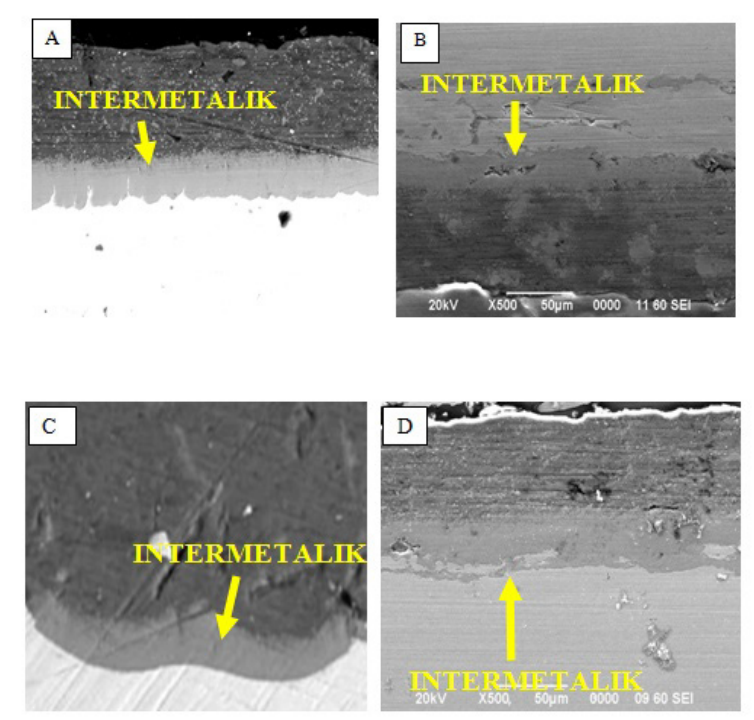

Gambar 5. Struktur Mikro Morfologi Lapisan Intermetalik (A) Al Murni, (B) $95 \% \mathrm{Al}+5 \% \mathrm{Si}$, (C) $90 \% \mathrm{Al}+10 \% \mathrm{Si}$, (D) $85 \% \mathrm{Al}+15 \% \mathrm{Si}$. 
Hasil struktur mikro penelitian pada Gambar 5 dan Gambar 6 menunjukkan bahwa semakin besar Si ditambahkan, maka semakin halus morfologi finger-like. Morfologi tersebut sangat tidak menguntungkan untuk sifat ketahanan aus dan kestabilan thermal dari lapisan yang terbentuk. Untuk aplikasi turbin dibutuhkan antarmuka lapisan intermetalik yang rata dan halus, sebab tegangan dapat terkonsentrasi pada antarmuka yang tidak rata dan dapat menyebabkan retak pada saat material digunakan.

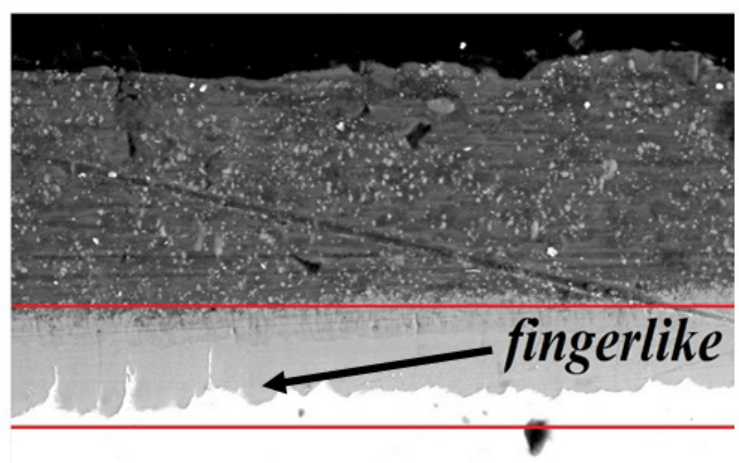

Gambar 6. Struktur mikro sampel Al murni waktu pencelupan 3 menit dengan morfologi finger-like pada lapisan intermetalik.

Selain morfologi finger-like pada lapisan intermetalik, dapat ditemukan juga beberapa poros, inklusi, dan crack pada lapisan yang ditunjukkan oleh Gambar 7 . Hal ini dapat disebabkan oleh beberapa faktor, yaitu adanya udara atau hidrogen yang terjebak pada saat proses hot dip aluminizing dan tidak adanya pengaturan tekanan gas sehingga menghasilkan porositas atau inklusi yang disebabkan kurangnya kebersihan lelehan akibat slag atau pengotor yang muncul pada saat proses hot dip aluminizing. Sementara, crack yang timbul dapat disebabkan oleh ketidakmampuan logam untuk menyusut secara natural pada titik yang mengalami perbedaan tekanan (Wang and Shi 2004).

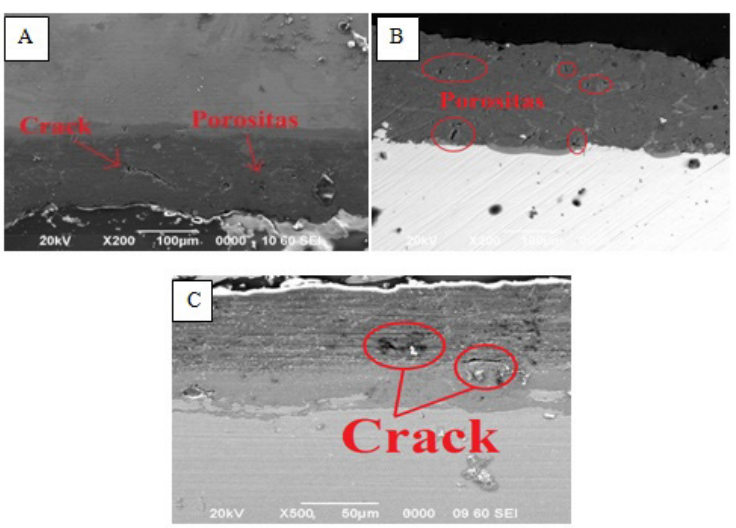

Gambar 7. Porositas dan Crack pada lapisan (A) 5\% Si 1 menit, (B) 10\% Si 1 menit, (C) $15 \% \mathrm{Si}$ 1 menit.

Penambahan silikon pada bath, dipercaya dapat menghilangkan atau menghaluskan morfologi finger-like pada komposisi silikon lebih dari 6\%wt (Citrawati and Mabruri 2009). Pada morfologi finger-like tersebut ditemukan adanya senyawa $\mathrm{Fe}_{2} \mathrm{Al}_{5}$ yang jika dilakukan penambahan silikon akan membentuk senyawa $\mathrm{Fe}_{\mathrm{x}} \mathrm{Al}_{\mathrm{y}} \mathrm{Si}_{z}$, sehingga pertumbuhan $\mathrm{Fe}_{2} \mathrm{Al}_{5}$ tersebut dapat direduksi oleh adanya difusi dengan silikon.

\section{Pengaruh Komposisi dan Waktu Pencelupan Hot Dip Aluminizing terhadap Lapisan Intermetalik}

Komposisi lelehan menggunakan Al murni dilakukan pada temperatur overheat $150^{\circ} \mathrm{C}$, yaitu $811^{\circ} \mathrm{C}$ dengan waktu pencelupan 1,3 , dan 5 menit diperoleh lapisan intermetalik. Berdasarkan diagram fasa $\mathrm{Fe}-\mathrm{Al}$ dapat ditentukan senyawa yang terkandung dalam lapisan tersebut mengacu pada komposisi (wt \%) dan temperatur. Tabel 1 menunjukkan komposisi kandungan lapisan intermetalik terhadap temperatur lelehan dengan kode sampel A (Al murni), B $(95 \% \mathrm{Al}+5 \% \mathrm{Si})$, C $(90 \% \mathrm{Al}+10 \% \mathrm{Si})$, D $(85 \% \mathrm{Al}+15 \% \mathrm{Si})$, dan angka $1,3,5$ adalah waktu berdasarkan menit. 
Tabel 1. Komposisi pada Lapisan Intermetalik

\begin{tabular}{cccccc}
\hline Sampel & \multicolumn{3}{c}{ Komposisi (\%at.) } & $\begin{array}{c}\text { Indentifi- } \\
\text { kasi Fasa }\end{array}$ \\
& $\mathrm{Al}$ & $\mathrm{Fe}$ & $\mathrm{Si}$ & $\mathrm{Cr}$ & \\
\hline $\mathrm{A} 1$ & 59,92 & 32,67 & 2,17 & 5,24 & $\mathrm{FeAl}_{2}$ \\
$\mathrm{~A} 3$ & 61,11 & 31,71 & 1,88 & 5,29 & $\mathrm{FeAl}_{2}$ \\
$\mathrm{~A} 5$ & - & - & - & - & - \\
B1 & 64,19 & 28,61 & 4,03 & 3,16 & $\mathrm{FeAl}_{2}$ \\
B3 & 62,26 & 29,75 & 3,97 & 4,02 & $\mathrm{FeAl}_{2}$ \\
B5 & - & - & - & - & - \\
C1 & 65,97 & 19,47 & 10,88 & 3,68 & $\mathrm{FeAl}_{3} \mathrm{Si}$ \\
C3 & 53,65 & 33,3 & 7,16 & 5,89 & $\mathrm{FeAl}_{2} \mathrm{Si}$ \\
$\mathrm{C} 5$ & 60,58 & 27,29 & 7,65 & 4,48 & $\mathrm{FeAl}_{2} \mathrm{Si}$ \\
D1 & 68,47 & 12,77 & 14,62 & 4,14 & $\mathrm{FeAl}_{3} \mathrm{Si}$ \\
D3 & 66,23 & 14,47 & 13,32 & 5,97 & $\mathrm{FeAl}_{3} \mathrm{Si}$ \\
D5 & 62,21 & 17,45 & 15,48 & 4,86 & $\mathrm{FeAl}_{3} \mathrm{Si}$ \\
\hline
\end{tabular}

Pada sampel dengan komposisi penambahan $15 \% \mathrm{Si}$ pada waktu pencelupan 1 menit diperoleh 68,47\%at Al, 12,77\%at Fe, dan $14,62 \%$ at $\mathrm{Si}$ dengan $\mathrm{FeAl}_{3} \mathrm{Si}$ sebagai senyawa dominan pada lapisan tersebut. Sampel dengan waktu pencelupan 3 menit diperoleh $66,23 \%$ at $\mathrm{Al}, 14,47 \%$ at $\mathrm{Fe}$, dan 13,32\%at Si dengan senyawa dominan pada lapisan tersebut adalah $\mathrm{FeAl}_{3} \mathrm{Si}$. Sampel dengan waktu pencelupan 5 menit diperoleh $62,21 \%$ at Al, $17,45 \%$ at $\mathrm{Fe}$, dan $15,48 \%$ at $\mathrm{Si}$ dengan senyawa dominan pada lapisan tersebut adalah $\mathrm{FeAl}_{3} \mathrm{Si}$. Karakteristik dari fasa $\mathrm{FeAl}_{3} \mathrm{Si}$ mempunyai karakteristik yang lebih getas dibandingkan $\mathrm{FeAl}_{2} \mathrm{Si}$ yang mempunyai sifat ulet (Eggeler, Auer, and Kaesche 1986; Ei-Mahallawy et al. 1997).

Senyawa yang terkandung dari lapisan intermetalik antara lain $\mathrm{FeAl}_{2} \mathrm{FeAl}_{2} \mathrm{Si}$, dan $\mathrm{FeAl}_{3} \mathrm{Si}$. Hal yang membedakan senyawasenyawa tersebut adalah jumlah atom $\mathrm{Fe}$ dan atom Al pada tiap lapisan intermetalik. Pada lapisan yang mengandung banyak Fe (Fe-Rich) akan lebih ulet dibandingkan lapisan intermetalik yang mengandung banyak Al (Al-Rich) yang mempunyai sifat getas (brittle). Hal ini menyebabkan aplikasi yang akan digunakan, yakni sudu turbin pada turbin uap dibutuhkan material yang ulet dan tahan aus sehingga kegagalan dapat dikendalikan. Berdasarkan Tabel 1, sampel dengan keuletan tertinggi yaitu dengan kandungan atom Fe pada lapisan intermetalik terbesar yaitu pada sampel dengan penambahan $10 \% \mathrm{Si}$ dengan senyawa $\mathrm{FeAl}_{2} \mathrm{Si}$ (Zhong-xiang Gui, Weikang Liang, Zhang Yisheng 2014).

\section{Pengaruh Komposisi dan Waktu Pencelupan, Heat Treatment terhadap Lapisan Intermetalik Hot Dip Aluminizing}

Setelah dilakukan proses hot dip aluminizing, kemudian dilakukan heat treatment terhadap sampel pada temperatur $700^{\circ} \mathrm{C}$ selama 3 jam dalam muffle furnace yang dilakukan di Laboratorium Metalurgi LIPI Serpong. Sampel yang mewakili proses heat treatment ini adalah sampel dengan waktu pencelupan 3 menit dari tiap komposisinya. Setelah itu, pengamatan struktur mikro dilakukan dengan menggunakan SEM-EDS di Laboratorium Pusat Penelitian Metalurgi dan Material LIPI.

Gambar 8 merupakan hasil pengamatan struktur mikro dari lapisan setelah heat treatment sampel Al murni. Lapisan intermetalik setelah heat treatment diperoleh senyawa dominan yaitu $\mathrm{Fe}$ dan Al. Tingginya komposisi $\mathrm{Cr}$ pada substrat juga mempengaruhi lapisan intermetalik, sehingga lapisan tersebut mengandung persenyawaan $\mathrm{Cr}$. Atom-atom $\mathrm{Cr}$ yang berdifusi ke arah lapisan intermetalik, selain membentuk persenyawaan dengan $\mathrm{Fe}$ dan $\mathrm{Al}$ juga membentuk presipitat $\mathrm{Al}_{\mathrm{x} \text { - }}$ $\mathrm{Cr}_{\mathrm{y}}$ ketika atom-atom $\mathrm{Cr}$ mencapai lapisan alumunium (Citrawati and Mabruri 2009). Dari hasil SEM-EDS dapat ditunjukkan presipitat tersebut pada lapisan yang menyerupai jarum sebagai bentuk persenyawaan Fe, Al, dan Cr. Crack yang muncul pada lapisan difusi disebabkan adanya deformasi plastis yang tinggi pada saat 
sampel dipanaskan (Kobayashi and Yakou 2002). Namun, dengan penambahan unsur Si dalam campuran hot dip aluminizing dapat menghilangkan crack pada lapisan $\mathrm{FeAl}_{2}$, hal tersebut ditunjukkan pada Gambar 10 - Gambar 12.

Pada penelitian sebelumnya, ditunjukkan hasil yang berbeda, yakni suhu pemanasan di atas $600^{\circ} \mathrm{C}$ dapat memunculkan crack pada lapisan AlSi (Weikang Liang, Wenjie Tao, Bin Zhu, Zhang Yisheng, 2017). Hal tersebut kemungkinan disebabkan adanya pengaruh komposisi kimia dari substrat baja yang mengandung boron, sedangkan baja yang digunakan pada penelitian ini tidak menggandung boron.

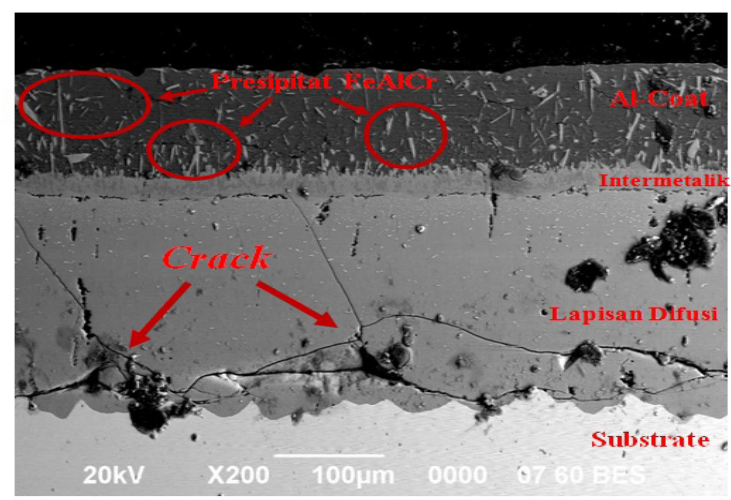

Gambar 8. Foto struktur mikro lapisan setelah heat treatment sampel Al murni.

Unsur yang dominan pada lapisan intermetalik setelah proses heat treatment adalah $\mathrm{Fe}$ dan $\mathrm{Al}$, sedangkan unsur $\mathrm{Si}$ lebih menyukai berdifusi dengan Al karena unsur tersebut mempunyai konsentrasi atau nomor atom yang hampir sama, yakni Al dengan nomor atom 13 dan Si dengan nomor atom 14. Tabel 2 dan Gambar 9-Gambar 12 menunjukkan distribusi komposisi (at\%) dan identifikasi fasa pada lapisan.
Tabel 2. Komposisi (\%at) Lapisan Intermetalik Setelah Proses Heat Treatment

\begin{tabular}{ccccc}
\hline \multirow{2}{*}{ Sampel } & \multicolumn{3}{c}{ Komposisi (at.\%) } & \multicolumn{2}{c}{ Indentifikasi } \\
& $\mathrm{Al}$ & $\mathrm{Fe}$ & $\mathrm{Cr}$ & $\mathrm{Fasa}$ \\
\hline Al Murni & 61,66 & 33,55 & 4,79 & $\mathrm{FeAl}_{2}$ \\
95\%Al+5\% Si & 55,46 & 38,74 & 5,8 & $\mathrm{FeAl}_{2}$ \\
$90 \% \mathrm{Al}+10 \% \mathrm{Si}$ & 48,84 & 38,32 & 3,43 & $\mathrm{FeAl}$ \\
$85 \% \mathrm{Al}+15 \% \mathrm{Si}$ & 69,6 & 29,97 & 1,49 & $\mathrm{FeAl}_{2}$ \\
\hline
\end{tabular}

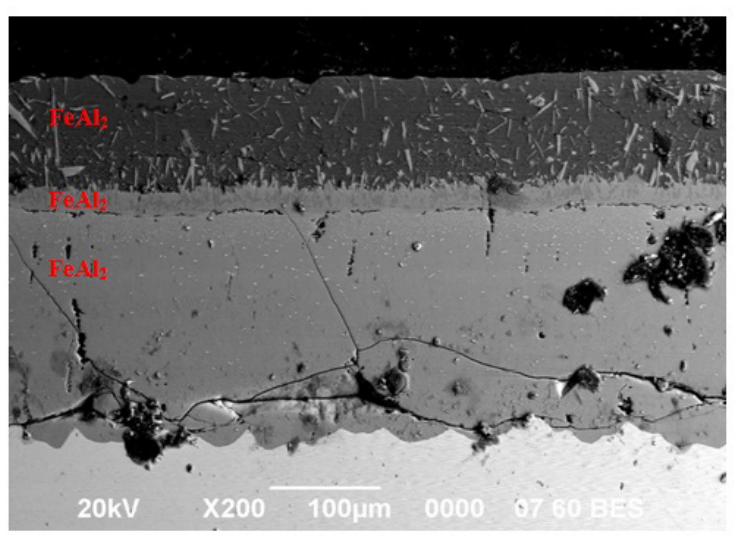

Gambar 9. Foto struktur mikro lapisan setelah heat treatment sampel Al murni.

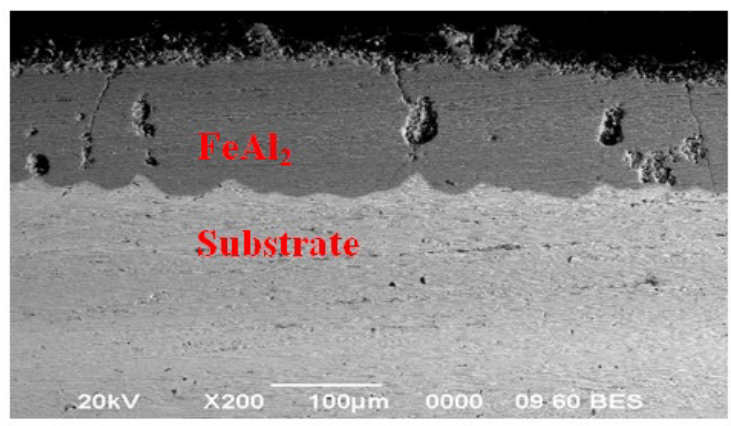

Gambar 10. Foto struktur mikro lapisan setelah heat treatment sampel 5\% Si.

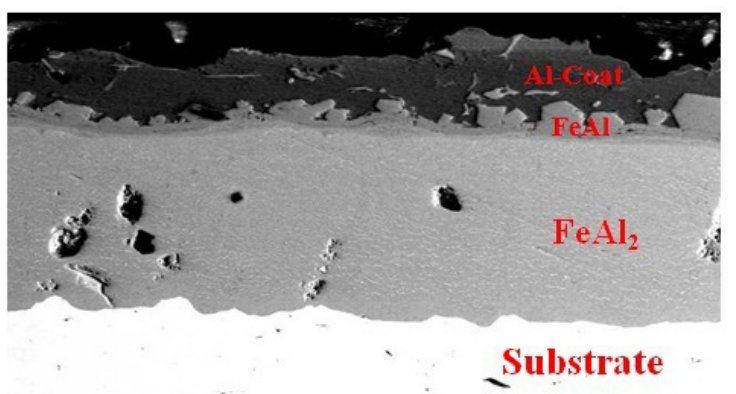

Gambar 11. Foto struktur mikro lapisan setelah heat treatment sampel $10 \% \mathrm{Si}$. 


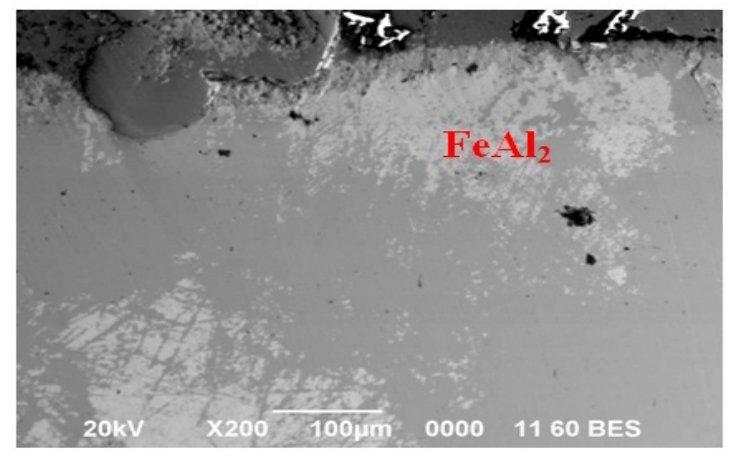

Gambar 12. Foto struktur mikro lapisan setelah heat treatment sampel 15\% Si.

\section{KESIMPULAN}

Berdasarkan hasil penelitian yang telah dilakukan, maka diperoleh kesimpulan sebagai berikut.

1. Pengaruh variasi waktu pencelupan pada proses hot dip aluminizing menunjukkan semakin lama waktu pencelupan, maka akan semakin besar nilai ketebalan lapisan pada komposisi Al Murni.

2. Lapisan difusi terbentuk setelah dilakukan proses laku difusi dengan sampel yang memiliki ketebalan lapisan difusi terbesar adalah 10\% Si.

3. Fasa yang terbentuk pada lapisan intermetalik hasil hot dip aluminizing umumnya adalah $\mathrm{FeAl}_{2}$ dan $\mathrm{FeAl}_{3} \mathrm{Si}$.

4. Pengaruh penambahan unsur Si pada komposisi lelehan mengakibatkan semakin besar penambahan unsur Si. Dengan demikian, akan semakin halus morfologi fingerlike pada lapisan terbentuk, tetapi penambahan unsur $\mathrm{Si}$ menghambat pertumbuhan difusi pada lapisan.

\section{UCAPAN TERIMA KASIH}

Terima kasih kami ucapkan kepada Pusat Penelitian Metalurgi dan Material (P2MM) LIPI yang telah memfasilitasi dan membimbing dalam pengujian pada proses penelitian dan kepada jurusan teknik metalurgi UNTIRTA yang telah membimbing hingga proses penelitian selesai dengan baik.

\section{REFERENCES}

Awan, G.H., and F. ul Hasan. 2008. "The Morphology of Coating/Substrate Interface in Hot-Dip-Aluminized Steels." Mater. Sci. Eng. A 472 (1-2): 157-65.

Citrawati, Fataya, and Efendi Mabruri. 2009. "Pelapisan Aluminium Baja Tahan Karat Martensitik AISI 420 Melalui Metode Celup Panas." Metalurgi 2 (2): 1-8.

Ebrahimifar, Hadi, Morteza Zandrahimi, Bahaedin Nikrooz, and Mehdi Sedighi. 2013. "Production of Cobalt Anti-Corrosion Coating on AISI 430 Steel-Optimization Using Box-Behnken Experimental Designs." Indian Journal of Chemical Technology 20 (1): 40-45.

Eggeler, G., W. Auer, and H. Kaesche. 1986. "On the Influence of Silicon on the Growth of the Alloy Layer during Hot Dip Aluminizing." J. Mater. Sci. 21 (9): 3348-3350.

Ei-Mahallawy, N. A., M. A. Taha, M. A. Shady, A. R. Ei-Sissi, A. N. Attia, and W. Reif. 1997. "Analysis of Coating Layer Formedon Steel Strips during Aluminising by Hot Dipping in Al-Si Baths." Materials Science and Technology 13 (10): 832-40. https://doi. org/10.1179/mst.1997.13.10.832. 
Kobayashi, S, and T Yakou. 2002. "Control of Intermetallic Compound Layers at Interface between Steel and Aluminum by Diffusion-Treatment." Mater. Sci. Eng. A 338 (1-2): 44-53.

Liu, Xingbo, Ever Barbero, Ling Xu, Matthew Burris, Keh-Minn Chang, and Vinod Sikka. 2005. "Liquid Metal Corrosion of $316 \mathrm{~L}, \mathrm{Fe} 3 \mathrm{Al}$, and FeCrSi in Molten Zn-Al Baths." Metallurgical and Materials Transactions A 36 (8): 2049-58.

Saidi, D., B. Zaid, N. Souami, M. Negache, and A. Si Ahmed. 2014. "Microstructure and Fracture Mode of a Martensitic Stainless Steel Steam Turbine Blade Characterized via Scanning Auger Microscopy and Potentiodynamic Polarization." In $I O P$ Conf. Series: Materials Science and Engineering, 012004. IOP Publishing. https://doi.org/10.1088/1757899X/60/1/012004.

Wang, D., and Z. Shi. 2004. "Aluminizing and Oxidation Treatment of 1Cr18Ni9 Stainless Steel." Appl. Surf. Sci. 227 (1-4): 255-260.
Wang, Liang, Wenjie Tao, Bin Zhu, Zhang Yisheng. 2017. "Influence of heating parameters on properties of the Al-Si coating applied to hot stamping." Science China Technological Sciences 60 (7): 1-15.

WANG, Qian, Xue-song LENG, Tian-hao YANG, and Jiu-chun YAN. 2014. "Effects of $\mathrm{Fe}-\mathrm{Al}$ Intermetallic Compounds on Interfacial Bonding of Clad Materials." Trans. Nonferrous Met. Soc. China 24: 279-284.

Zhong-xiang, Gui, Weikang Liang, Zhang Yisheng. 2014. "Enhancing ductility of the Al-Si coating on hot stamping steel by controlling the Fe-Al phase transformation during austenitization." Science in China Series E Technological Sciences 57 (9): 1785-1793. https://doi: 10.1007/ s11431-014-5576-3. 